\title{
Ottomentality: neoliberal governance of culture and neo-ottoman management of diversity
}

\section{Chien Yang Erdem}

To cite this article: Chien Yang Erdem (2017) Ottomentality: neoliberal governance of culture and neo-ottoman management of diversity, Turkish Studies, 18:4, 710-728, DOI: 10.1080/14683849.2017.1354702

To link to this article: https://doi.org/10.1080/14683849.2017.1354702

曲 Published online: 06 Aug 2017.

Submit your article to this journal $\pi$

Џll Article views: 288

Q View related articles ๘

View Crossmark data ¿ 


\title{
Ottomentality: neoliberal governance of culture and neo-ottoman management of diversity
}

\author{
Chien Yang Erdem \\ Faculty of Art, Design and Architecture, Bilkent University, Ankara, Turkey
}

\begin{abstract}
This essay proposes an alternative concept - Ottomentality - in order to more adequately assess Turkey's growing neo-Ottoman cultural ensemble. This concept is deployed here to underscore the convergence of neoliberal and neo-Ottoman rationalities and the discursive practices that are developed around them for governing culture and managing a diverse society. The essay contends that the convergence of these two rationalities has significantly transformed the state's approach to culture as a way of governing the social, constituted a particular knowledge of multiculturalism, and a subject of citizenry increasingly subjected to exclusion and discipline for expressing critical views of this knowledge.
\end{abstract}

ARTICLE HISTORY Received 30 September 2016; Accepted 22 May 2017

KEYWORDS Neo-Ottomanism; neoliberalism; governmentality; culture; Justice and Development Party (Adalet ve Kalkınma Partisi; AKP)

\section{Introduction}

In 2012, the Turkish blockbuster The Conquest 1453 (Fetih 1453; Fetih hereafter), depicting the monumental Ottoman conquest of Istanbul, was acclaimed for its domestic and international box-office success. The film was funded by the Ministry of Culture and Tourism with the aim of promoting Turkish cinema, as a national brand, in the global film industry. ${ }^{1}$ It is the most expensive production of the Turkish film industry to date. The ruling Justice and Development Party (Adalet ve Kalkınma Partisi, AKP) government officials praised the film as 'the best film ever made in the past years' since it 'represented all the events having occurred during the conquest.' Fetih is an ideal product of the AKP government's renewed cultural policy, which considers such cultural productions as cinema as a means for preserving national culture and creating a national brand for Turkey to compete in the global market. ${ }^{3}$ Since the Ottoman-Islamic cultural heritage is an essential component in the AKP's vision of national culture - a civilization of 
tolerance and peaceful coexistence of different cultures and faiths - it plays a central role in the processes of cultural preservation and nation branding.

Between 2011 and 2014, the Turkish television historical drama Magnificent Century (Muhteşem Yüzyıl, Muhteşem hereafter), featuring the life of the sixteenth century Ottoman Sultan Süleyman, also attracted wide viewership in Turkey and abroad, especially in the Balkans and the Middle East. Although the series generated increasing interests in Turkey's tourism and Ottoman-Islamic arts and history, it received more than 70,000 individual complaints from local audience, ${ }^{4}$ government officials' criticism, and warning of being taken off the air from Radio and Television Supreme Council (Radyo ve Televizyon Üst Kurulu; RTÜK). The criticisms pointed at the series' historical (in)accuracy, (mis)representation of the revered Sultan as a hedonist, and harm to society's traditional values. As the then Prime Minister Recep Tayyip Erdoğan denounced, '[those] who toy with [traditional] values would be taught a lesson within the premises of law. ${ }^{5}$ The controversy over Muhteșem reveals the AKP government's endeavor in not only reviving the Ottoman-Islamic cultural heritage, but also establishing a moral-religious ethical code of social conduct. As Erdoğan once stated, it is the AKP government's mission to 'raise a generation that is conservative and democratic and embraces the values and historical principles of its nation. ${ }^{6}$

Fetih and Muhteșem are two contrasting examples of the emergent cultural ensemble of Ottoman-themed productions and sites that have proliferated over the last decade. This cultural edifice, ranging from television series to history museums, is marked by its civil society-based and market-oriented characteristics. Before the 2000s, this cultural phenomenon would be unthinkable since the secularist state perceived the Ottoman-Islamic past as an obstacle to the nation's modernization and thus restricted its presence from public cultural life. Contemporary analyses that focus on this emergent cultural phenomenon often associate it with the AKP's neo-Ottomanism generally understood as an Islamist ideology and/or foreign policy seeking to transform Turkey's national identity based on the Ottoman-Islamic cultural heritage. ${ }^{7}$ Nonetheless, the cases of Fetih and Muhteşem reveal a more complex and contradictory relation between this cultural phenomenon and the neo-Ottomanist ideology. While some productions may collide with the neo-Ottomanist narrative, others seem to stray away from it. Since the reproduction of this cultural ensemble entails complex governing processes involving both the government and civil society, it may be insufficient to suggest that it is merely a cultural facet of the neo-Ottomanist ideology and/or foreign policy. In this regard, the analytical concept of neo-Ottomanism seems to fall short for comprehending current form of neo-Ottomanism. How does one understand the discrepancy of this emergent neo-Ottoman cultural ensemble, which has a seemingly coherent shape? What are the forces 
that gave rise to this unprecedented cultural phenomenon, which was unthinkable before the 2000s? What are the socio-political implications of this emergent cultural form that may be overlooked by the conceptions of neo-Ottomanism as an 'ideology' and 'foreign policy'? And if the concept of neo-Ottomanism has rather limited analytical utility, what could be a more useful perspective for investigating Turkey's renewed Ottoman motto?

This article takes the cases of Fetih and Muhteşem as a departure point to reconsider the analytical concept of neo-Ottomanism in order to more adequately explain the emergent cultural phenomenon. It undertakes three tasks to address the above questions. First, through a brief historical overview of the different phases of (neo-)Ottomanism between the late Ottoman period and present, the article intends to illustrate the fluctuating characteristic of neo-Ottomanism. This overview allows us to conceive neo-Ottomanism as a historically contingent social process, where its configuration is constantly changing and at times merging with other forces. Second, by critically engaging with the common conceptions of neo-Ottomanism as 'ideology' and 'foreign policy,' the article argues that contemporary studies that adopt these two approaches may run the risk of overlooking the complexity of the latest phase of neo-Ottomanism, and hence may underestimate its effects on society. Finally, by incorporating the Foucauldian perspective of governmentality, the article proposes the concept of Ottomentality as an alternative approach to the latest phase of neo-Ottomanism. The article contends that cultural analyses may benefit from this perspective as it opens up new investigative questions for assessing the market-oriented and society-based characteristics of the current phase of neo-Ottomanism.

\section{Phases of neo-Ottomanism}

It is important to note that neo-Ottomanism is neither a novel nor a monolithic Islamist political thought of the AKP. Its historical roots can be traced back to the late Ottoman period and it has continued to evolve throughout the history of the Turkish Republic. Hakan Övünç Ongur points out four distinct phases in which (neo-)Ottomanism has (re)emerged as a means to respond to the different socio-political questions at particular historical moments. ${ }^{8}$ Ottomanism was first formulated during the late Ottoman reform (Tanzimat 1839-1876) period as an 'elitist multicultural project' to mitigate the growing nationalist movements and prevent the disintegration of the Ottoman Empire. 9 Initiated as a criticism of the Tanzimat reform policies, inspired by the European civilization and political model, Ottomanism was an opposing component emphasizing that the only way to rebuild unity among Ottoman subjects was to construct an Ottoman identity based on common cultural, historical, and traditional traits rather than blindly adopting the European model. Therefore, the Young Ottomans attempted to 
incorporate elements of Islam, pluralism, and imperialism to construct a new Ottoman subject that would be loyal to the Empire. ${ }^{10}$

However, Ottomanism in its second phase of evolution, during the founding period of the Turkish republic, was depoliticized and conceived of as a sign of backwardness and opposition to the state's modernization project. The early republican elite's radical reforms, which included the formation of the Turkish Language Institute ${ }^{11}$ and Turkish History Thesis, ${ }^{12}$ were efforts of systemic erasure of the Ottoman past and construction of a new Turkish national identity based on common linguistic and historical ties. Yet, the state's repression did not entirely diminish the ideas of Ottomanism. For instance, in the 1970s, a group of secular and conservative businessmen, intellectuals, and politicians founded an organization called the Hearths of the Enlightened (Aydınlar Ocağı) in which the Turkish-Islamic synthesis was developed. ${ }^{13}$ This synthesis was formulated to redefine Turkish identity by incorporating the component of Islamic civilization as an essential part of Turkish culture. ${ }^{14}$ The Turkish-Islamic synthesis has played an important role in the rise of Turkish political Islam and the reformulation of neo-Ottomanism in the following decades. ${ }^{15}$

In its third phase of evolution during the 1980s and 1990s, neo-Ottomanism was reformulated as a new framework for resolving socio-cultural tensions resulting from cultural diversity and a renewed diplomatic strategy focusing on regions of former Ottoman territory. ${ }^{16}$ According to Y1lmaz Çolak, Turgut Özal was a leading figure in perpetuating Ottomanism as the core of a political vision based on a new collective memory, for a new form of foreign policy, and social contract' by incorporating 'Ottoman plur-

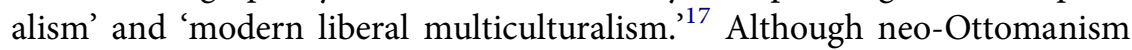
briefly lost its momentum after Özal's death in 1993, it continued to have its influence in the discourses of the Islamist Welfare Party (Refah Partisi), which formed a coalition government with the Right Path Party (Dogrru Yol Partisi) led by Tansu Çiller in $1995 .{ }^{18}$ Informed by the ideas of its predecessor National Outlook (Milli Görüş) and Özal's vision of institutionalizing 'a new model of cultural pluralism based on the Ottoman legacy,' ${ }^{19}$ the Welfare Party's neo-Ottomanism 'rejected the ethnic version of Turkish nationalism and reinterpreted Turkish identity on the basis of regional and religious grounds (multiethnic and multireligious bases) and cosmopolitan liberal values. ${ }^{, 20}$ Until this point, neo-Ottomanism had served as an opponent responding to the republican elites' efforts at nation building, modernization, secularization. It had continued to invoke the OttomanIslamic heritage in the public sphere to subvert the republican version of modernity, historiography, and national identity. ${ }^{21}$ The Ottoman-Islamic heritage was also utilized as a pragmatic means in policies to mitigate the escalating social tension resulting from identity-based claims, most notably, the Alevi and Kurdish questions. ${ }^{22}$ 
Since 2002, after the AKP came to power and having consecutively ruled as a single-party government, neo-Ottomanism has entered its latest phase of transformation. It has become the governing power, instead of being an oppositional force for decades. According to Ongur, by evoking the Ottoman past, the AKP in its early years of governance had attempted to create a liberal-conservative socio-political framework, 'which defined its political agenda within the boundaries of human rights, liberal-economic development and social conservatism. ${ }^{23}$ As he remarks, what distinguishes the AKP's neo-Ottomanism from the Özalian version and makes it more politically sustainable is its prioritization of and strong connection with civil society. This connection is compellingly evident in the wide spectrum of social practices and cultural expressions. As he observes, the Ottoman theme has been promulgated through such everyday practices as entertainment productions, Ottoman language teaching in secondary schools, and urban designs and projects. Employing Michael Billig's notion of 'banal nationalism, ${ }^{24}$ he names this latest phase of neo-Ottomanism 'banal Ottomanism':

[Unlike] under Ozal's neo-Ottomanism, during the AKP era Ottomanism's social dimension appears to be prioritized [...] This process is not carried out by the government exclusively; once established, society itself assumes the pivotal role in promulgating Ottoman images [...] As current 'banal Ottomanism' is perpetuated through practice by society itself, it therefore also functions as mechanism of re-identification alienating today's society from that of the Republican era. ${ }^{25}$

Hence, according to Ongur, the latest phase of neo-Ottomanism continues to function as a 're-identification process' in which the neo-Ottomanist nationalist ideology is promulgated by the society itself and becomes a part of the mundane everyday practice.

Ongur's historical overview of the evolution of (neo-)Ottomanism is useful as it allows the conception of neo-Ottomanism as a contingent social process that its configuration and meaning alter at different historical junctures. Nonetheless, as the cases of Fetih and Muhteşem reveal, the latest phase of neo-Ottomanism seems to be a more complex process than an ideological revolution and break from Kemalism as Ongur suggests. The ideological work is indeed one of the most nuanced characteristics of current neo-Ottomanism, and hence the society's active role in reproducing 'banal Ottomanism' may be interpreted as an indication of the triumph of the neoOttomanist hegemons. But, how does this approach explain such cases as Muhteşem in which the society, rather than the government, plays a vital role in popularizing the Ottoman-Islamic past yet condemned by the public and disciplined by such regulatory practice as media censorship? This article argues that the conceptions of neo-Ottomanism as 'ideology' and 'foreign policy' are insufficient for explaining the discursive and micro- 
practices that constitute the complex and hybrid configuration of neo-Ottomanism. Hence, in order to address this question, a critical evaluation of the concept of neo-Ottomanism is necessary.

\section{A critique of the concept of neo-Ottomanism}

Although neo-Ottomanism was initially formulated by a collaborated group of secular, liberal intellectuals and conservative Turkish political actors in the 1980s, it is mostly associated with the consolidated socioeconomic and political power of the conservative elites. In current Turkish domestic and foreign politics analyses, neo-Ottomanism is commonly conceptualized as a political ideology, or 'doctrine' (often referring to Ahmet Davutoğlu's Strategic Depth serving as the guidebook for Turkey's diplomatic strategy in the twenty-first century), which seeks to construct a new national identity and reshape foreign policy. ${ }^{26}$ It has become a key concept in domestic and foreign politics analyses especially after Ahmet Davutoglu was appointed as the Foreign Minister in 2009. As Darko Tanasković defines,

neo-Ottomanism is mostly taken to signify a complex macro-ideological platform according to which present day Turkey, as a legitimate civilization heir of the Ottoman Empire, should reaffirm its entire spiritual, cultural and political legacy so that it could secure and effectively play the role of a global force to reckon within the undergoing shift of power balance and influence in the world. $^{27}$

When conceptualized as an Islamist ideology and foreign policy of the postCold War era, neo-Ottomanism is perceived as a competing counterpart of Kemalism. This ideology serves as the referential point for Turkey's foreign policy in the context of a changing global order. ${ }^{28}$ For its advocates, neo-Ottomanism is the antidote for the authoritarian, state-centric, and top-down projects of secularization and modernization. It is an alternative to the rigidly defined unitary Turkish identity defined by ethnic and linguistic characteristics, which have failed to encompass large segments of the ethnically diverse society. It is argued that by invoking the shared Ottoman heritage, incorporating Islam, and combining the ideas of Ottoman millet ${ }^{29}$ and modern liberal multiculturalism, the decades-long Kurdish question and other identity-based social issues could be resolved. ${ }^{30}$ As Özal once remarked, 'I believe that the most powerful single constituting element of identity in this society is Islam. ${ }^{31}$ As a crucial element of neo-Ottomanism, Islam is seen as the bonding element of society and a 'liberal' quest as it proclaims to 'transcend ethnic differences' and unite the citizens on the basis of their common Muslim identity. ${ }^{32}$ On the contrary, critics of neo-Ottomanism suggest that despite its emphasis on liberal multiculturalism, it fails to produce a more inclusive socio-political model as it claims to do. The neo-Ottomanists' 
selective reading of and pragmatic approach to the Ottoman past and its persistence on Islam as the ethical code and binding element for the diverse society nonetheless fails to acknowledge the ethno-religious differences and the demands for cultural rights of its citizens. ${ }^{33}$

Notwithstanding the two camps of argument, one thing that the advocates and critics of neo-Ottomanism have in common is that they both conceive of neo-Ottomanism as an ideological shift and identity politics resulting from a political struggle in opposition to Kemalism. Although this interpretation is helpful for understanding the two major competing narratives of the Turkish nation, it has produced persistent dichotomies of Kemalism vs. neo-Ottomanism and secularism vs. Islamism. It also has produced certain analytical trajectories, which may have undermined the explanatory value of neo-Ottomanism in not only Turkish domestic and foreign politics, but also the cultural milieu.

First, the 'ideology' and 'policy' conceptions tend to perceive neo-Ottomanism as a monolithic, state-centric, hegemonic imposition upon society. It presumes that this ideology, when implemented into domestic and foreign policy, somehow has an effect on how the society perceives and renews its 'national interest' and 'identity.' For instance, Hakan Yavuz argues that Turkey's identity and foreign policy formulations are inseparable processes. According to him, the rise of neo-Ottomanism during the 1980s and 1990s served as a form of Islamist nationalism seeking to redefine Turkey's national identity on the bases of a common Ottoman-Islamic heritage and further influence its diplomatic strategy within the region. In his comparative analysis of the neo-Ottomanist and Kemalist foreign policy approaches, Ömer Taşpınar similarly suggests the intertwined relationship between Turkish national identity and foreign policy. He points to the similarity between Kemalism and neo-Ottomanism (both the Özalian and AKP versions) that, despite their different approaches to the Kurdish question and foreign policy in the Balkans, Central Asia, and Middle East, 'at the end of the day, both Kemalism and neo-Ottomanism share a state-centric view of the world and Turkish national interests. ${ }^{34}$ Yavuz's and Taşpınar's arguments reflect the common conception of neo-Ottomanism as an Islamist nationalist ideology that its consolidation since the 1980s has a direct impact on Turkey's national interest and understanding of what the Turkish nation means, that is, a shift from Kemalism to neo-Ottomanism.

However, as Fatma Müge Göçek criticizes, the connection between nationalist ideology, national interest, and identity in such analyses as Taşpınar's remains unclear and questionable. Her sociological perspective suggests that each social group, i.e. the Armenians, Greeks, or Kurds, may perceive its relationship with the 'Turkish nation' differently than the one promulgated by the Kemalist or neo-Ottomanist nationalist ideology. Göçek's perspective also leads one to question the often taken-for-granted view of the ideological 
function and hegemonic effect of neo-Ottomanism in transforming the collective memory and identity of Turkish society - a claim that is often made in current cultural debates. The ideological claim has had an influence on how cultural analysts understand the neo-Ottomanization of Turkey's cultural field. For instance, in her discussions of the Miniatürk theme park and the 1453 Panorama History Museum, Şeyda Barlas Bozkuş argues that these two sites are crucial for understanding the 'AKP's neo-Ottomanist nationalist ideology $[\ldots]$ in creating a new class of citizens with a new relationship to Turkish-Ottoman national identity. ${ }^{35}$ The problem of this view is that it tends to assume that these cultural sites function as merely representational devices of the neo-Ottomanist ideology.

The ideological function of the emergent Ottoman-themed cultural forms is indeed indubitable. Yet, as mentioned earlier, neo-Ottomanism in Turkey's current cultural field has taken a unique form, which not only prioritizes the society but is also practiced by the society itself. Neo-Ottomanism, in its current phase, is not merely a set of ideas articulated by political actors as a way of negotiating what the Turkish nation means in domestic and foreign politics, but tangible practices and objects that are commodified and consumed as commercial products in everyday life. It is also important to note that current neo-Ottomanism is often practiced based on market principles, which involves the withdraw of the state's role as a provider of arts and culture to the public, transformation of the cultural sphere into a free market, and reduction of the state's intervention to ensure the functioning of the free market of culture. The relationship between neo-Ottomanism and neoliberalism will be discussed shortly, but at this point some questions arise. How does one explain the current phase of neo-Ottomanism, which cannot be reduced as a set of Islamist ideas seeking to produce a new collective memory, history, and identity of Turkey? How does one make sense of Turkey's current cultural neo-Ottomanization that is not practiced exclusively by the state and government, but more often in a privatized, commercialized, and market-oriented fashion? And what is the significance of this particular cultural form of neo-Ottomanism for Turkish society?

These questions lead to the second critique of the 'ideology' and 'foreign policy' conceptions of neo-Ottomanism. These two conceptions tend to fail to acknowledge the hybrid and complex characteristics of the current phase of neo-Ottomanism, which often relies on and blends with other political projects such as the ongoing European Union (EU) accession, globalization, and neoliberalism. They tend to assume that the neo-Ottomanist ideology is internally consistent and implemented straightforwardly into (foreign) policy, which further has a hegemonic effect on how the society perceives its collective identity. However, when closely examined, current forms of what Ongur describes as 'banal Ottomanism' are more likely to reveal the discursive processes and interwoven relations of neo-Ottomanism with other 
political strategies, projects and programs. When taking into account the seemingly disconnected forces, it is possible to identify a distinctive configuration of neo-Ottomanism that is currently at question as well as the various coordinates at which neo-Ottomanism and other political thoughts, strategies, policies, and projects intersect. Moreover, it is also likely to identify the internal inconsistencies of neo-Ottomanism as the cases of Fetih and Muhteşem illustrate.

Recent studies on Turkey's experience with neoliberalism reveal overlapping relationships between several political forces that are pertinent for reassessing the concept of neo-Ottomanism and comprehending the neoOttoman cultural phenomenon in Turkey today. These overlapping relationships are feasible in the areas of urban renewal projects, ${ }^{36}$ emergent forms of social service provision, ${ }^{37}$ health and family care programs, ${ }^{38}$ national education, ${ }^{39}$ and cultural policy. ${ }^{40}$ This body of literature underscores that Turkey's accelerated EU accession between the late 1990s and mid-2000s provided timely opportunity for the conservative democratic AKP government to pursue economic, social, and political reforms. These studies perceive neoOttomanism as a tactic of the AKP government aiming at realigning society's norms and moral values based on a selective, pragmatic interpretation of Sunni Islam and Ottoman-Islamic heritage. As Yıldız Atasoy suggests, the Ottoman-Islamic heritage is central for the AKP to promulgate an Ottoman-Islamic civilizational discourse, which sees Turkey as the center of world civilization. According to her, the AKP has tactically blended the Ottoman-Islamic culture, heritage, and tradition with the European values of liberal democracy, human rights, and freedom of expression and formulated an alternate version of universalism that is authentic, homegrown, and characteristically neoconservative. ${ }^{41}$ Atasoy's useful insight of the unique combination of neoliberalism and Islam(ism) may offer a way for rethinking neo-Ottomanism beyond the 'ideology' and 'foreign policy' trajectories. Her meticulous analysis of Turkey's experiment with neoliberalism illustrates that neo-Ottomanism always relies on opportune political moments and various political projects for advancing its agenda. Her view therefore allows us to acknowledge the hybrid, complex, and fluctuating characteristics of neo-Ottomanism that it exists not as a coherent ideology or an established set of policies, but very much depends on the discourses, policies, and strategies of EU negotiation between the late 1990s and mid-2000s, neoliberalism, globalization, and democratization that without which its formulation would not have been possible.

\section{From neo-Ottomanism to Ottomentality}

In order to more adequately assess the socio-political significance of Turkey's emergent neo-Ottoman cultural phenomenon, this article 
proposes a conceptual shift from neo-Ottomanism to Ottomentality. This shift involves not only rethinking neo-Ottomanism as a form of governmentality, but also thinking of neoliberal and neo-Ottoman rationalities in collaborative terms. According to Foucault, governmentality is 'understood in the broad sense of techniques and procedures for directing human behavior. Government of children, government of souls and consciences, government of a household, of a state, or of oneself. ${ }^{42}$ Here, this study is concerned with the government of culture and diversity under the AKP's administration. This approach is less concerned with a particular political ideology or the question of 'how to govern.' and more about the 'different styles of thought, their conditions of formation, the principles and knowledge that they borrow from and generate, the practices they consist of, how they are carried out, their contestations and alliances with other arts of governing. ${ }^{43}$ This approach sees that neoliberalism and neo-Ottomanism are two interdependent forces that when they converge, they generate new modes of governing the cultural life of society based on market and neoconservative rationalities. The AKP's endeavor in transforming such social provisions and public services as culture in line with neoliberal rationality enables it to create ever-new spheres of freedom - the market - in which private individuals become autonomized and responsible for exercising their rights to freedom (of choice, lifestyle, expression, etc.) through their active participation in the emergent culture market. It is through the private individuals' own exercise of freedom in the market that they become subjugated to the disciplinary practices of managing culture and diversity. On the one hand, the individuals are obliged to comply with the rules of the market; they must conduct themselves as entrepreneurs and consumers so as to become active and responsible citizens. On the other hand, they are also obliged to act in accordance with a set of moral-religious rules and a multireligious and multiethnic social order based on a selective and pragmatic interpretation of Ottoman-Islamic pluralism. The multiple discourses, strategies, and policies concerning Turkey's EU negotiation, globalization, economic growth, democratization, and cultural governance therefore constitute a whole new set of ethical codes for directing conducts of the emergent spheres of freedom. And through their autonomy, the free individuals become subjugated to the government of culture and diversity. Hence, as Foucault notes, this double movement 'between the technologies of domination of the others and those of the self is what he calls 'governmentality.' ${ }^{, 44}$

Neo-Ottomanism is conceived here as Turkey's current form of neoconservatism, a prevalent political rationality that its governmental practices are not solely based on a politicized view of Islam and Islamic values, but also draws from and produces a new political culture that considers Ottoman-Islamic civilization, its model of toleration and pluralism in 
particular, as the foundation of multicultural democracy for Turkey. Neoliberalism, in the same vein, far from a totalizing concept describing an established set of political ideology or economic policy, is understood here as a historically contingent and locally specific form of governmentality that must be analyzed by taking into account the multiple political forces which gave its unique configuration in Turkey. ${ }^{45}$ In light of this perspective, and for practical purposes, Ottomentality is an alternative concept that is developed here to avoid the ambiguity, competing meanings, and analytical limitations of neo-Ottomanism. This concept underscores the convergence of neoliberalism and neo-Ottomanism as well as the interrelated discourses, projects, policies, and strategies that are developed around them for governing cultural activities and regulating diversity in Turkey. It pays specific attention to the techniques and practices that aim at transforming culture and reshaping society. It is concerned with the production of knowledge, or truth, based on which a new social reality of multicultural democracy based on a selective view of Ottoman millet is constituted. Furthermore, it helps to identify the type of political subject, whose demand for cultural rights and participatory democracy is reduced to market terms and a narrow understanding of multiculturalism. And their criticism of this new social reality is increasingly subjected to judicial exclusion and discipline.

It should be noted that Ottomentality is an authoritarian type of governmentality - a specific type of illiberal rule operated within the structure of modern liberal democracy. As Mitchell Dean notes, although the literature on governmentality has focused mainly on liberal democratic rules that are practiced through the individual subjects' active role and exercise of freedom, there are also 'non-liberal and explicitly authoritarian types of rule that seek to operate through obedient rather than free subjects, or, at a minimum, endeavor to neutralize any opposition to authority. ${ }^{46}$ He suggests that a useful way to approach this type of governmentality would be to identify the practices and rationalities that 'divide' or 'exclude' those who are subjected to be governed. ${ }^{47}$ According to Foucault's notion of 'dividing practices,' ' $\mathrm{t}$ ] he subject is either divided inside himself or divided from others. This process objectivizes him. Examples are the mad and the sane, the sick and the healthy, the criminals and the "good boys." 48 Turkey's growing neoOttoman cultural ensemble can be considered as such exclusionary practices which seek to regulate the diverse culture by dividing the subjects into categorical, if not polarized, segments based on their cultural differences. For instance, mundane practices such as going to the museum and investing in television productions may produce such divided subjects as the pious and the secular, the moral and the degenerate, and the Sunni-Muslim-Turk and the ethno-religious minorities. 


\section{Reassessing the neo-ottoman cultural phenomenon through the lens of Ottomentality}

Fetih and Muhteşem are vital cases through which the recent neo-Ottomanization of Turkey's cultural field will be reassessed. The two cases are particularly pertinent as they reveal the complex, hybrid, and internally contradictory characteristics of current phase of neo-Ottomanism in Turkey. They also present a compelling example of the discursive, dividing practices entailed in constituting a governable subject of citizenry. As the AKP's cultural intervention in line with neoliberal rationality transforms the cultural field into an integral part of the free market, it creates new spheres of freedom wherein individuals conduct themselves and in relation with the others in accordance with market imperatives. Active civil participation, in the forms of entrepreneurship and consumption in this culture market, is regarded as a norm and means of exercising freedom and democracy. It is through the active citizens' own exercise of freedom (of choice, lifestyle, expression, etc.) that they become subjugated to such regulatory practices as media censorship, sponsorship law, and cultural policy, etc. Hence, these governmental practices constitute a subject of citizenry divided within and among themselves as they participate in the culture market.

According to Asu Aksoy, what differentiates the AKP's approach to cultural policy from the early republic's state-centered model is that the market mentality has become the administrative norm. ${ }^{49}$ With the aim of more efficiently managing such public services as culture, the AKP heavily relies on privatization as a means to limit the state's role in governance. The rationale of privatization entails that the responsibility of administering culture in such areas as television, theater, and cinema should be transferred to the civil society as to reduce the state's burden of providing public services. ${ }^{50}$ For instance, the reorganization of the media sector and administrative reform of Turkish Television and Radio Corporation (Türkiye Radyo Televizyon Kurumu; TRT) during the 2000s indicate the AKP's effort in transforming public cultural services into competitive markets wherein private initiatives take on active and responsible roles in providing the necessary capital and productions. ${ }^{51}$ By means of bidding, tax incentives, and ministerial funding, private sectors are encouraged to undertake governmental projects that aim at promoting Turkish culture on domestic and global platforms. For example, with the enactment of the new TRT law in 2008, TRT is now able to outsource its productions to private media companies and to generate revenue through the advertising market and sales of its productions. ${ }^{52}$ The collaboration between TRT and such private media companies as Animax, who produces Ottoman-themed programs for TRT Çocuk (children's) channel, is exemplary of the prioritization of private sector in AKP's cultural management. The case of TRT hence indicates that the strategy of 
privatization has opened up spheres of freedom for citizens to engage in participatory democracy in market terms. ${ }^{53}$

Nonetheless, the right to exercise freedom and participatory democracy through the market is not to be understood as without regulations or boundaries. As Wendy Larner notes, although neoliberalism is based on the idea of minimum state interference, 'it does not follow that there is less governance. ${ }^{, 54}$ As the Turkish media market encourages participation of private actors, the government must also invent new strategies and rules to guide them to produce the desirable type of culture that is in conformity with the government's vision for a virtuous society. Such media regulatory establishments as RTÜK and the General Directorate of Cinema thus play a crucial role in determining the 'good' and 'bad' media productions for the general public. The contrasting cases of Fetih and Muhteşem hence exemplify the government's carrot-and-stick technique in regulating the culture market and managing diversity.

In addition, the cases of Fetih and Muhteşem reveal the AKP's assertion of its moral-religious authority in the government of culture and diversity. Wendy Brown argues that, as the notion of nation state sovereignty becomes weakened by the processes of economic liberalization and globalization, the boundary that separates religion and state becomes blurred. As a result, religion becomes 'de-privatized' and surges back into the public sphere. ${ }^{55}$ In the Turkish context, this blurred boundary between religion and state has enabled the neoconservative AKP to establish links between moral-religious authority and state authority as well as between religious truth and political truth. These links are evident in the AKP officials' public statements declaring the government's moral mission of restoring Turkish culture in accordance with Islamic and traditional values. For instance, as Erdoğan reacted to his secular opponent's comment about the AKP's interference in politics with religious views, 'we [AKP] will raise a generation that is conservative and democratic and embraces the values and historical principles of its nation. ${ }^{56}$ According to his view, despite Muhteşem's contribution of generating growth in industries of culture and tourism, it became subjected to censorship and legal action because its content did not comply with the governing authority's moral mission. The controversy of Muhteşem illustrates the rise of a religion-based political truth in Turkey, which sees Islam as the primary reference for directing society's moral conduct and individual lifestyle. Henceforth, by rewarding desirable actions (with sponsorship law and tax incentives) and punishing undesirable ones (through censorship, media banishment, and jail term for media practitioners' misconduct), a divided subject of citizenry along moral-religious lines is constituted. As the market mechanisms enable the promulgation of moral-religious values, the active citizens are also offered a choice of identity as virtuous citizens, who should conduct their life and their relationship with the others based on Islamic 
norms and values. While exercising their freedom at the market place, the citizens are also reminded of their responsibility to preserve traditional value, family structure, and gender relations. Those who deviate from the norm are subjected to public condemnation and punishment.

Moreover, the AKP officials' praise for Fetih indicates its endeavor in a neo-Ottomanist knowledge. This knowledge perceives Islam as the centripetal force for enhancing social cohesion by transcending differences between faith and ethnic groups. It rejects candid and critical interpretations of history and insists on a singular view of Ottoman-Islamic pluralism and a pragmatic understanding of the relationship between religion and state. ${ }^{57}$ It does not require historical accuracy since religious truth is cast as historical and political truth. For instance, a consistent narrative of the conquest can be observed in such productions the film Fetih. This narrative begins with the Prophet Muhammad's prophecy of the Ottoman conquest of Istanbul. When history is narrated from a religious point of view, it becomes indisputable as it would imply challenge to religious truth, hence God's will. Nonetheless, the neo-Ottomanist knowledge conceives of the conquest not only as an Ottoman victory in the past, but an incontestable living truth in Turkey's present. As Nevzat Bayhan, former general manager of Culture Inc. (Kültür A.S.) in association with the Istanbul Metropolitan Municipality, stated at the opening ceremony of Istanbul's Panorama 1453 History Museum,

The conquest [of Istanbul] is not about taking over the city [...] but to make the city livable $[. .$.$] and its populace happy. Today, Istanbul continues to present to$ the world as a place where Armenians, Syriacs, Kurds [...] Muslims, Jews, and Christians peacefully live together. ${ }^{58}$

Bayhan's statement illustrates the centrality of the 1453 conquest in the neoOttomanist knowledge because it marks the foundation of a civilization of tolerance, diversity, and peaceful coexistence in Turkey. While the neo-Ottomanist knowledge may conveniently serve the branding purpose for promoting Turkey in the global context, it more significantly rationalizes the governmental practices in reshaping the inter-ethnic and inter-faith relations in Turkey. The knowledge also produces a political norm of indifference - one that is reluctant to recognize ethno-religious differences among populace, uncritical of the limits of Islam-based cultural pluralism, and more significantly, indifferent about state-sanctioned discrimination and violence against the ethnoreligious minorities.

As the neo-Ottomanist cultural ensemble reproduces and mediates a neoOttomanist knowledge in such commodities as the film Fetih, consumer citizens are exposed to a new set of symbolic meanings of Ottoman-Islamic toleration, pluralism, and peaceful coexistence, albeit through a view of the Ottoman past fixated on its 'magnificence' rather than its 'monstrosity. ${ }^{.59}$ This knowledge sets the norm for private citizens to think of themselves in 
relation to the other ethno-religious groups based on a hierarchical social order, which subordinates minorities to the rule of Sunni Islamic government. When this imagery of magnificence serves as the central component in nation branding, it encourages citizens to take pride and identify with their OttomanIslamic heritage. As such, Turkey's nation branding perhaps also can be considered as a novel technology of the self as it requires citizens, be it business sectors, historians, or filmmakers, to take on their active role in building an image of tolerant and multicultural Turkey through arts and culture. It is in this regard that neo-Ottomanism is considered as a form of governmentality as it produces a citizenry, who actively participates in the reproduction of neoOttomanist knowledge and continues to remain uncritical about the 'dark legacy of the Ottoman past. ${ }^{60}$ Consequently, Ottomentality has produced a type of subject that is constantly subjected to dividing techniques 'that will divide populations and exclude certain categories from the status of the autonomous and rational person. ${ }^{61}$

\section{Conclusion}

This article has proposed a reconceptualization of neo-Ottomanism as a form of governmentality in order to more adequately assess the significance of the emergent neo-Ottoman cultural ensemble on Turkish society. This conceptual move calls for a critical engagement with the conventional interpretations of neo-Ottomanism as an ideology and foreign policy. It also entails new inquiries for analyzing the micro-governmental practices that aim at shaping individual cultural conducts and inter-cultural relations. As the cases of Fetih and Muhteşem illustrate, Turkey's renewed Ottoman motto reveals not only a re-identification process of Turkish culture with the Ottoman-Islamic past, but also new modalities of governing culture and managing diversity. The article maintains that it is through such an engagement with the multiple and intersecting political rationalities, strategies, and policies of cultural governance that one can begin to understand the significance of the seemingly mundane and dispersed practices of the neoOttoman cultural ensemble on the social. Thus, such a conceptual move is necessary as it offers alternative and more productive ways of analysis through which discussions of potential political and cultural intervention may be generated.

\section{Notes}

1. See the mission and vision of the General Directorate of Cinema at http://www. sinema.gov.tr/TR,143919/misyon-ve-vizyon.html.

2. Bülent Arınç's statement about the film on the AKP official website. https:// www.akparti.org.tr/site/haberler/son-yillarda-cekilmis-en-muhtesem-film/ 20422. 
3. See note 1 above.

4. The New York Times, March 17, 2011.

5. Hurriyet Daily News, December 8, 2014.

6. Hurriyet Daily News, February 2, 2010.

7. Çolak, "Ottomanism vs. Kemalism"; Tanasković, "Neo-Ottomanism”; Taşpınar, "Between Neo-Ottomanism and Kemalism"; Onar, "Neo-Ottomanism" and "Echoes"; Yavuz, "Turkish Identity."

8. Ongur, "Ottomanisms."

9. Ibid., 417.

10. Ibid., 417-8.

11. Aytürk, "Turkish Linguists."

12. Atakuman, "Cradle or Crucible."

13. Zurcher, Turkey, 288.

14. See note 8 above.

15. Çolak, "Ottomanism vs. Kemalism"; Onar, "Neo-Ottomanism" and Tanasković, "Neo-Ottomanism."

16. Çolak, "Ottomanism vs. Kemalism."

17. Çolak, "Ottomanism vs. Kemalism," 587 and 591-2.

18. Ibid., 595.

19. Ibid., 592.

20. Ibid., 593.

21. Çınar, Modernity.

22. See note 16 above.

23. Özbudun, "Conservative Democracy," cited in Ongur "Ottomanisms," 424.

24. Billig, Banal Nationalism.

25. Ongur, "Ottomanisms," 425.

26. Çolak, "Ottomanism vs. Kemalism”; Taşpınar, "Between Neo-Ottomanism and Kemalism”; Onar, “Neo-Ottomanism”; Kınıklığlu, “Neo-Ottoman' Turkey?” and "Return of Ottomanism" in Today's Zaman, March 20, 2007, and "Return of Ottomanism II" in Today's Zaman, March 27, 2007; and Yavuz, "Turkish Identity."

27. Tanasković, "Neo-Ottomanism," 11.

28. Kınıklığlu, “'Neo-Ottoman' Turkey?" and Şahin, "An Axis Shift?.”

29. The Ottoman millet system was a normative and administrative practice of multi-religious rule. See Barkey, "Rethinking Ottoman Management."

30. Kinıklığlu "Return of Ottomanism," I \& II.

31. Özal quoted in Yavuz, "Turkish Identity," 24.

32. Ibid.

33. Aktürk, "Islamic Millet."

34. Taşpınar, "Between Neo-Ottomanism and Kemalism," 17.

35. Bozkuş, "1453 Conquest Museum," 1.

36. Potuoğlu-Cook, "Beyond the Glitter"; Dinçer, "Neoliberal Policies"; Karaman, "Urban Neoliberalism"; Lelandais, "Neoliberal Conservatism."

37. Zencirci, "Neoliberal Islam."

38. Acar and Altunok, "Politics of Intimate."

39. İnal and Akkaymak, Neoliberal Transformation.

40. Ada and Ayça İnce (eds.), Cultural Policy in Turkey and Ada, Turkish Cultural Policy Report.

41. Atasoy, Islam's Marriage with Neoliberalism.

42. Foucault, Ethics, 81. 
43. Rose, O’Malley and Valverde, "Governmentality," 84.

44. Foucault, Ethics, 225.

45. I follow Wendy Larner's argument that there are different variants of neoliberalism in locally specific contexts.

46. Dean, Governmentality, 155.

47. Ibid., 156.

48. Foucault, "The Subject and Power," 208.

49. Aksoy, "Atatürk Cultural Center."

50. Ibid., 196-201.

51. Sümer and Adakl1, "Public Service Broadcaster."

52. Ibid.

53. Dinçer et al. suggest that the AKP's model of cultural management conceives of 'public-private capital partnership [...] as a vital step towards greater democracy.' They argue that the AKP's model of participatory democracy narrowly defined in market terms nonetheless fails to provide platforms for enhancing social dialogue, diversity, and cultural rights. See "Historic and Cultural Heritage," 226-7.

54. Larner, "Neo-liberalism," 12.

55. Brown, "American Nightmare," 705-10.

56. Hurriyet Daily News, February 2, 2010.

57. Barkey, "Rethinking Ottoman Management," 12-3.

58. Milliyet, February 3, 2010 (my translation).

59. Asuman Suner uses the term 'magnificence' to refer to the popularization of the Ottoman past in Turkish films during the 2000s and the term 'monstrosity' to refer to the cynical societal attitude towards critical views about the Ottoman history and state-sanctioned collective violence against minorities. See "Between Magnificence and Monstrosity."

60. Göçek, Transformation of Turkey, Introduction Chapter.

61. Dean, Governmentality, 156.

\section{Acknowledgements}

I would like to thank Prof. Dr Alev Çınar and my colleagues Petra Cafnik Uludağ, Jermaine S. Ma, Nazlı Pınar Kaymaz, and Christina Ann Hamer for their intellectual and moral support throughout the process of writing this article. I am also grateful to the anonymous reviewers for their valuable comments on an earlier draft of this article.

\section{Disclosure statement}

No potential conflict of interest was reported by the author.

\section{Note on contributor}

Chien Yang Erdem is a Ph.D. candidate at the Faculty of Art, Design and Architecture at Bilkent University, Ankara, Turkey. Her research areas include cultural studies, media studies, and Turkish studies. This publication is part of the author's work in progress during her doctoral research conducted at Bilkent University. 


\section{References}

Acar, Feride, and Gülbanu Altunok. "The 'Politics of Intimate' at the Intersection of Neo Liberalism and Neo-conservatism in Contemporary Turkey." Women's Studies International Forum 41 (November 2013): 14-23.

Ada, Serhan, ed. Turkish Cultural Policy Report: A Civil Perspective. Istanbul: Istanbul Bilgi University Press, 2011.

Aksoy, Asu. “The Atatürk Cultural Center and AKP's 'Mind Shift' Policy.” In Introduction to Cultural Policy in Turkey, edited by Serhan Ada and H. Ayça Ince, 191-212. Istanbul: Bilgi University Press, 2009.

Aktürk, Sener. "Persistence of the Islamic Millet as an Ottoman Legacy: Mono-religious and Anti-ethnic Definition of Turkish Nationhood." Middle Eastern Studies 45, no. 6 (November 1, 2009): 893-909.

Atakuman, Çiğdem. "Cradle or Crucible: Anatolia and Archaeology in the Early Years of the Turkish Republic (1923-1938).” Journal of Social Archaeology 8, no. 2 (June 1, 2008): 214-235.

Atasoy, Yıldiz. Islam's Marriage with Neoliberalism: State Transformation in Turkey. New York: Palgrave Macmillan, 2009.

Aytürk, İlker. "Turkish Linguists against the West: The Origins of Linguistic Nationalism in Atatürk's Turkey." Middle Eastern Studies 40, no. 6 (2004): 1-25.

Barkey, Karen. "Rethinking Ottoman Management of Diversity." Chap. 1 In Democracy, Islam and Secularism in Turkey, edited by Ahmet Kuru and Alfred Stepan, 12-31. New York: Columbia University Press, 2012.

Billig, Michael. Banal Nationalism. Los Angeles: Sage, 1995.

Bozkuş, Şeyda Barlas. "Rethinking Nationalism in the Case of 1453 Conquest Museum in Istanbul." Global Media Journal: Turkish Edition 4, no. 8 (2014): 1-12.

Brown, Wendy. "American Nightmare: Neoliberalism, Neoconservatism, and Dedemocratization.” Political Theory 34, no. 6 (December 1, 2006): 690-714.

Çinar, Alev. Modernity, Islam, and Secularism in Turkey: Bodies, Places, and Time. 1st ed. Minneapolis: University of Minnesota Press, 2005.

Çolak, Yılmaz. "Ottomanism vs. Kemalism: Collective Memory and Cultural Pluralism in 1990s Turkey.” Middle Eastern Studies 42, no. 4 (July 2006): 587-602.

Dean, Mitchell M. Governmentality: Power and Rule in Modern Society. 2nd ed. London: Sage, 2009.

Dinçer, İclal. "The Impact of Neoliberal Policies on Historic Urban Space: Areas of Urban Renewal in Istanbul.” International Planning Studies 16, no. 1 (February 1, 2011): 43-60.

Dinçer, Iclal, Zeynep Enlil, Deniz Ünsal, Burcu Yılmaz, and Emre Karabacak. "Historic and Cultural Heritage." In Turkish Cultural Policy Report: A Civil Perspective, edited by Serhan Ada, 221-231. Istanbul: Istanbul Bilgi University Press, 2011.

Foucault, Michel. Ethics: Subjectivity and Truth, edited by Paul Rabinow and Robert Hurley. New York: New Press, 1997.

Foucault, Michel. “The Subject and Power.” In Michel Foucault: Beyond Structuralism and Hermeneutics, edited by Hubert L. Dreyfus and Paul Rabinow, 208-226. Brighton: Harvester, 1982.

Göçek, Fatma Müge. The Transformation of Turkey: Redefining State and Society from the Ottoman Empire to the Modern Era. London: I.B.Tauris, 2011.

İnal, Kemal and Akkaymak, Güliz. Neoliberal Transformation of Education in Turkey: Political and Ideological Analysis of Educational Reforms in the Age of the AKP. London: Springer, 2012. 
Karaman, Ozan. "Urban Neoliberalism with Islamic Characteristics." Urban Studies 50, no. 6 (December 1, 2013): 3412-3427.

Kınıklığlu, Suat. “'Neo-Ottoman' Turkey?” Project Syndicate, December 3, 2009. https://www.project-syndicate.org/commentary/-neo-ottoman--turkey.

Larner, Wendy. "Neo-Liberalismi Policy, Ideology, Governmentality." Studies in Political Economy 63, no. 1 (2000): 5-25.

Lelandais, Gülçin Erdi. "Urbanisation under Neoliberal Conservatism in Turkey." Research Turkey 4, no. 7 (July 2015): 54-67.

Onar, Nora Fisher. "Neo-Ottomanism, Historical Legacies and Turkish Foreign Policy." Centre for Economic and Foreign Policy Studies, Discussion Paper Series, 2009.

Ongur, Hakan Övünç. "Identifying Ottomanisms: The Discursive Evolution of Ottoman Pasts in the Turkish Presents." Middle Eastern Studies 51, no. 3 (May 4, 2015): 416-32.

Potuoğlu-Cook, Öykü. "Beyond the Glitter: Belly Dance and Neoliberal Gentrification in Istanbul." Cultural Anthropology 21, no. 4 (November 1, 2006): 633-660.

Rose, Nikolas, Pat O'Malley, and Mariana Valverde. "Governmentality." Annual Review of Law and Social Science 2, no. 1 (December 2006): 83-104.

Sümer, Burcu, and G. Adaklı. "Public Service Broadcaster as a Market Player: Changing Operational Patterns of the TRT in Turkey under the AKP Leadership, 2002-2010.” Public Service Media after Recession, 2010, 8-11.

Suner, Asuman. "Between Magnificence and Monstrosity: Turkishness in Recent Popular Cinema." New Perspectives on Turkey 45, no. Special Issue-1 (September 2011): 123-154.

Tanasković, Darko. "Neo-Ottomanism: A Doctrine and Foreign Policy Practice." Association of Non-governmental Organisations of Southeast Europe-CIVIS, 2013.

Taşpınar, Ömer. “Turkey's Middle East Policies: Between Neo-Ottomanism and Kemalism.” Carnegie Endowment for International Peace, October 7, 2008.

Yavuz, M. Hakan. "Turkish Identity and Foreign Policy in Flux: The Rise of Neo Ottomanism.” Critique: Critical Middle Eastern Studies 7, no. 12 (March 1998): $19-41$.

Zencirci, Gizem. "Neoliberal Islam and Emergent Forms of Social Service Provision in Turkey - Project on Middle East Political Science." Accessed January 25, 2017. https://pomeps.org/2014/09/29/neoliberal-islam-and-social-service-provision-inturkey/.

Zurcher, Erik J. Turkey: A Modern History. 3rd ed. London: I.B.Tauris, 2004. 